Article

\title{
Zn-Zr-Al oxides derived from hydrotalcite precursors for ethanol conversion to diethyl carbonate
}

\author{
Jian Zhang, Tingting Yan, Yusen Yang, Jialue Sun, Yanjun Lin *, Min Wei \# \\ State Key Laboratory of Chemical Resource Engineering, Beijing Advanced Innovation Center for Soft Matter Science and Engineering, Beijing University \\ of Chemical Technology, Beijing 100029, China
}

\section{A R T I C L E I N F O}

\section{Article history:}

Received 29 October 2018

Accepted 5 January 2019

Published 5 April 2019

\section{Keywords:}

Hydrotalcite

Metal oxides

Acid-base catalytic reactions

Ethanol conversion

\begin{abstract}
A B S T R A C T
Ethanol conversion to high-value-added products has attracted considerable attention in both academic research and industrial fields. In this study, we synthesized a series of tunable acid-base bifunctional $\mathrm{Zn}-\mathrm{Zr}$-Al metal oxides (represented as $\mathrm{Zn}_{2} \mathrm{Zr}_{x} \mathrm{Al}-\mathrm{MMO}$ ) in light of the structural topotactic transformation of $\mathrm{Zn}_{2} \mathrm{Zr}_{x} \mathrm{Al}$-hydrotalcite precursors $\left(\mathrm{Zn}_{2} \mathrm{Zr}_{x} \mathrm{Al}-\mathrm{LDH}\right)$. The resulting $\mathrm{Zn}_{2} \mathrm{Zr}_{x} \mathrm{Al}-\mathrm{MMO}$ catalysts were employed in the conversion of ethanol to diethyl carbonate. $\mathrm{The} \mathrm{Zr}^{4+}$ ion content of the $\mathrm{LDH}$ precursor plays a key role in modulating the acid-base properties and determining catalytic performance: the $\mathrm{Zn}_{2} \mathrm{Zr}_{0.1} \mathrm{Al}-\mathrm{MMO}$ sample exhibits the optimal catalytic behavior with a diethyl carbonate (DEC) yield of $42.1 \%$, which is the highest reported for metal oxide catalysts. Structure-property correlation investigations revealed that the synergic catalysis between medium-strong basic sites and weak acid sites plays a predominant role in the catalytic behavior. Furthermore, in situ Fourier transform infrared measurements showed that the weak acidic site promotes activation adsorption of the reactant (urea) and the intermediate product (ethyl carbamate), while the medium-strong basic site accelerates ethanol activation. Moreover, the $\mathrm{Zn}_{2} \mathrm{Zr}_{0.1} \mathrm{Al}-\mathrm{MMO}$ catalyst has the advantages of cost effectiveness, good stability, and reusability. Therefore, the acid-base bifunctional catalysts developed in this work can be employed as promising candidates in acid-base catalytic reactions such as ethanol conversion.
\end{abstract}

(C) 2019, Dalian Institute of Chemical Physics, Chinese Academy of Sciences. Published by Elsevier B.V. All rights reserved.

\section{Introduction}

Ethanol (EtOH) is regarded as a renewable platform chemical for the synthesis of versatile high value-added products [1-4], due to its low cost, large-scale industrial manufacture from biomass fermentation [5,6]. Diethyl carbonate (DEC) is an important derivative of ethanol that is attracting increasing interest as a synthetic intermediate and green solvent [7], with the merits of low toxicity, negligible pollution, and low bio-accumulation. Moreover, it is an ideal substitute for the traditional fuel additive methyl tert-butyl ether (MTBE), due to its higher oxygen content and superior gasoline/water distribution coefficient [8]. To date, several approaches have been developed for the synthesis of DEC from ethanol: the reaction of ethanol with (a) phosgene [9], (b) urea [10-13], (c) carbon monoxide [14,15], and (d) a dialkyl carbonate [16-18]. Among these methods, ethanolysis of urea has attracted a great deal of attention due to the advantages of cost effectiveness and facile

\footnotetext{
* Corresponding author. Tel: +86-10-64412131; Fax: +86-10-64425385; E-mail: linyj@mail.buct.edu.cn

\# Corresponding author. Tel: +86-10-64412131; Fax: +86-10-64425385; E-mail: weimin@mail.buct.edu.cn

This work was supported by the National Key R\&D Program (2017YFA0206804), the National Natural Science Foundation of China (21871021, 21521005), and the Fundamental Research Funds for the Central Universities (buctylkxj01, XK1802-6)

DOI: S1872-2067(19)63318-8 | http://www.sciencedirect.com/science/journal/18722067 | Chin. J. Catal., Vol. 40, No. 4, April 2019
} 
manipulation and product separation processes $[19,20]$. This reaction is comprised of two consecutive steps: the formation of intermediate ethyl carbamate (EC) from ethanol and urea, followed by reaction of EC and ethanol to produce DEC. Traditionally, organometallic compounds, metal salts, and metal oxides have been employed for ethanolysis of urea and its analogs, among which zinc oxide ( $\mathrm{ZnO})$ has shown a high $\mathrm{DEC}$ yield. It has been determined that the acid-base properties dominate the catalytic performance of $\mathrm{ZnO}[10,21,22]$, but the role of the acidic and basic sites in the ethanolysis of urea remains ambiguous. Moreover, the $\mathrm{ZnO}$ catalyst suffers from dissolution and transformation to the homogeneous complex $\mathrm{Zn}(\mathrm{NCO})_{2}\left(\mathrm{NH}_{3}\right)_{2}$ during the reaction process [23]. This stimulated us to further tune the acid-base properties of $\mathrm{ZnO}$-based catalysts to achieve significantly improved catalytic performance and stability.

Layered double hydroxides (LDHs) (also known as hydrotalcites), with the general formula $\left[\mathrm{M}^{2+}{ }_{1-x} \mathrm{M}^{3+}{ }_{x}(\mathrm{OH})_{2}\right]\left(\mathrm{A}^{n-}\right)_{x / n} \cdot m \mathrm{H}_{2} \mathrm{O}$, are a type of anionic clay with positively charged, brucite-like host layers, and exchangeable interlayer anions [24,25]. Recently, LDH materials, as solid acid-base catalysts and catalyst supports, have received a great deal of interest in the field of heterogeneous catalysis, due to their versatile, tunable chemical compositions, structures, and architectures [26,27]. In particular, by virtue of the so-called structural topotactic transformation process of LDH precursors, corresponding mixed metal oxide (MMO) catalysts can be obtained after calcination treatment [28], which possess tunable acid-base sites which depend on the chemical composition of, and preparation parameters from LDHs. This unique property inspired us to design and prepare MMO catalysts with tunable acid-base sites, for the purpose of attaining enhanced catalytic behavior toward the synthesis of DEC from ethanol and urea.

In this study, $\mathrm{Zn}_{2} \mathrm{Zr}_{x} \mathrm{Al}$-hydrotalcite precursors (denoted as $\mathrm{Zn}_{2} \mathrm{Zr}_{x} \mathrm{Al}-\mathrm{LDH}$ ) were synthesized using a co-precipitation method. Subsequently, a series of $\mathrm{Zn}-\mathrm{Zr}$-Al mixed metal oxide ( $\left.\mathrm{Zn}_{2} \mathrm{Zr}_{x} \mathrm{Al}-\mathrm{MMO}\right)$ catalysts were synthesized by phase topotactic transformation from LDH precursors and used in ethanol conversion to produce DEC. $\mathrm{CO}_{2}$ temperature programmed desorption ( $\mathrm{CO}_{2}$-TPD) and $\mathrm{NH}_{3}$-TPD studies indicated that the $\mathrm{Zr}$ content significantly influences the surface acidity and basicity of the $\mathrm{Zn}_{2} \mathrm{Zr}_{x} \mathrm{Al}$-MMO catalysts, and the $\mathrm{Zn}_{2} \mathrm{Zr}_{0.1} \mathrm{Al}$-MMO sample showed the maximal catalytic performance (DEC yield: 42.1\%), which is the highest in comparison with those of previously reported metal oxide catalysts (Table S1). In addition, the $\mathrm{Zn}_{2} \mathrm{Zr}_{0.1} \mathrm{Al}-\mathrm{MMO}$ catalyst exhibits good stability and reusability, with a loss in DEC yield of below $5 \%$ for up to five cycles. A study of structure-property correlations was performed: in situ FTIR results confirm that the weak acid site of $\mathrm{ZrO}_{2}$ is responsible for the activation adsorption of urea and the intermediate product, while the medium-strong basic site of $\mathrm{ZnO}$ accelerates ethanol activation.

\section{Experimental}

\subsection{Materials}

Analytical-grade chemicals, including $\mathrm{ZrO}\left(\mathrm{NO}_{3}\right)_{2} \cdot \mathrm{xH}_{2} \mathrm{O}$, $\mathrm{Zn}\left(\mathrm{NO}_{3}\right)_{2} \cdot 6 \mathrm{H}_{2} \mathrm{O}, \mathrm{Al}\left(\mathrm{NO}_{3}\right)_{3} \cdot 9 \mathrm{H}_{2} \mathrm{O}, \mathrm{Na}_{2} \mathrm{CO}_{3}, \mathrm{NaOH}$, ethanol, cyclohexanol, and urea were obtained from Sigma-Aldrich and all reagents were used without further purification.

\subsection{Preparation of ZnZrAl-LDH and ZnZrAl-MMO samples}

$\mathrm{Zn}_{2} \mathrm{Zr}_{x} \mathrm{Al}-\mathrm{LDH}$ precursors with $\mathrm{Zn}: \mathrm{Zr}: \mathrm{Al}$ molar ratios of 2 : $0: 1,2: 0.05: 1,2: 0.1: 1$, and $2: 0.2: 1$ were prepared using a co-precipitation method, as follows. Typically, Solution A was obtained by dissolving $\mathrm{ZrO}\left(\mathrm{NO}_{3}\right)_{2} \cdot x \mathrm{H}_{2} \mathrm{O}, \mathrm{Zn}\left(\mathrm{NO}_{3}\right)_{2} \cdot 6 \mathrm{H}_{2} \mathrm{O}$, and $\mathrm{Al}\left(\mathrm{NO}_{3}\right)_{3} \cdot 9 \mathrm{H}_{2} \mathrm{O}$, with varying $\mathrm{Zn}: \mathrm{Zr}: \mathrm{Al}$ molar ratios $\left(\left[\mathrm{Zn}^{2+}\right]\right.$ $\left.+\left[\mathrm{Al}^{3+}\right]+\left[\mathrm{Zr}^{4+}\right]=0.05 \mathrm{~mol} \mathrm{~L}^{-1}\right)$, in $100 \mathrm{~mL}$ of deionized water. Solution B was a mixture of $\mathrm{NaOH}\left(2 \mathrm{~mol} \mathrm{~L}^{-1}\right)$ and $\mathrm{Na}_{2} \mathrm{CO}_{3}(0.3$ mol $\left.\mathrm{L}^{-1}\right)$ in deionized water $(100 \mathrm{~mL})$. Solution $\mathrm{B}$ was added dropwise to Solution A with vigorous agitation until $\mathrm{pH}=10$ was obtained. The resulting slurry was heated at $110^{\circ} \mathrm{C}$ for 12 h. The resulting precipitate ( $\mathrm{Zn}_{2} \mathrm{Zr}_{x} \mathrm{Al}-\mathrm{LDH}$ precursors) was separated, washed thoroughly with deionized water, and dried at $60{ }^{\circ} \mathrm{C}$ for $24 \mathrm{~h}$. Finally, the $\mathrm{Zn}_{2} \mathrm{Zr}_{x} \mathrm{Al}-\mathrm{MMO}$ samples were obtained via calcination of $\mathrm{Zn}_{2} \mathrm{Zr}_{x} \mathrm{Al}-\mathrm{LDH}$ precursors at $500{ }^{\circ} \mathrm{C}$ for $4 \mathrm{~h}$ in air (heating rate $5^{\circ} \mathrm{C} \mathrm{min}^{-1}$ ).

\subsection{Catalyst characterization}

Powder X-ray diffraction (XRD) patterns were performed on a Rigaku XRD-6000 instrument ( $\mathrm{Cu} K_{\alpha}$ radiation: $\lambda=0.15418$ $\mathrm{nm} ; 40 \mathrm{kV}, 30 \mathrm{~mA}$ ). The UV-vis diffuse reflectance spectra (UV-vis DRS) were recorded on a Hitachi UV-vis spectrophotometer (U-3900H). The morphological study was carried out on a Zeiss Supra 55 scanning electron microscope (SEM) (accelerating voltage $20 \mathrm{kV}$ ). High resolution transmission electron microscopy (HRTEM) observation was carried out on a JEOL JEM-3010 at an accelerating voltage of $200 \mathrm{kV}$. Low-temperature $\mathrm{N}_{2}$ adsorption-desorption isotherms were recorded on a Quantachrome Autosorb-1C-VP analyzer. The sample was degassed at $200{ }^{\circ} \mathrm{C}$ for $12 \mathrm{~h}$; the multipoint Brunauer-Emmett-Teller (BET) method was used to calculate the total surface area.

The acidity and basicitiy of the catalysts were determined by using temperature-programmed desorption (TPD) of chemisorbed $\mathrm{NH}_{3}$ and $\mathrm{CO}_{2}$, carried out on a Micromeritics AutoChem II 2920 apparatus equipped with a thermal conductivity detector (TCD). For the $\mathrm{CO}_{2}$ or $\mathrm{NH}_{3}-\mathrm{TPD}, 100 \mathrm{mg}$ of sample was placed in a quartz tube reactor and pretreated in a helium flow $\left(50 \mathrm{~cm}^{3} \mathrm{~min}^{-1}\right)$ at a heating rate of $10{ }^{\circ} \mathrm{C} \mathrm{min}^{-1}$ to $500{ }^{\circ} \mathrm{C}$, and maintained at $500{ }^{\circ} \mathrm{C}$ for $1 \mathrm{~h}$, followed by cooling to $100{ }^{\circ} \mathrm{C}$. Afterwards, a flow of $\mathrm{CO}_{2}$ or $\mathrm{NH}_{3}$ was introduced into the sample for $0.5 \mathrm{~h}$ to obtain a saturation adsorption. Then, the catalyst was degassed in a helium flow for $1.5 \mathrm{~h}$ to remove physisorbed $\mathrm{CO}_{2}$ or $\mathrm{NH}_{3}$, followed by desorption measurements of $\mathrm{NH}_{3}$ or $\mathrm{CO}_{2}$ by heating from 100 to $550{ }^{\circ} \mathrm{C}$ at a rate of $10{ }^{\circ} \mathrm{C}$ $\min ^{-1}$.

In situ Fourier transform infrared (FTIR) spectra of urea, ethanol, and intermediate (EC) adsorbed onto catalyst samples were carried out using a Thermo Nicolet 380 spectrometer. Two types of measurements were performed, as follows. For 
urea or EC adsorption, the catalyst $(20 \mathrm{mg}$ ) and urea (or EC 2 $\mathrm{mg}$ ) were mixed thoroughly and pressed into a wafer. In the case of ethanol adsorption, the catalyst sample (20 mg) was pressed to obtain a wafer, which was then installed in the IR cell. Afterwards, ethanol was introduced into the cell for signal recording in the temperature range $30-200{ }^{\circ} \mathrm{C}$.

\subsection{Catalyst evaluation}

Catalytic reactions were performed using a $50-\mathrm{mL}$ stainless-steel autoclave equipped with a magnetic stirrer. Typically, $0.08 \mathrm{~g}$ of catalyst, $0.8 \mathrm{~g}$ of urea, and $9.2 \mathrm{~g}$ of ethanol were placed in the reactor, which was purged three times with $\mathrm{N}_{2}$, and then sealed. The reaction was triggered by heating the autoclave to a targeted temperature. The resulting product mixture was identified using off-line gas chromatography (Shimadzu GC-2014C, flame ionization detector). All detected products were quantitatively analyzed by the internal standard method using cyclohexanol as the internal standard.

A recyclability study of the catalyst was performed. The used catalyst was filtered from the mixed products, washed several times with ethanol and then dried. The obtained catalyst was reused for the next reaction cycle.

The yield of DEC (or EC) was determined by the following formula:

$$
Y=\frac{M}{\text { Starting urea (mol) }} \times 100 \%
$$

where $M$ stands for the cumulative mole number for DEC (or EC).

\section{Results and discussion}

\subsection{Structure and morphology studies}

The catalyst precursors, $\mathrm{Zn}_{2} \mathrm{Zr}_{x} \mathrm{Al}$-LDH with varying $\mathrm{Zr}$ contents, were prepared via a facile co-precipitation method. Their XRD patterns (Fig. 1 (A)) display a series of reflections at $2 \theta$

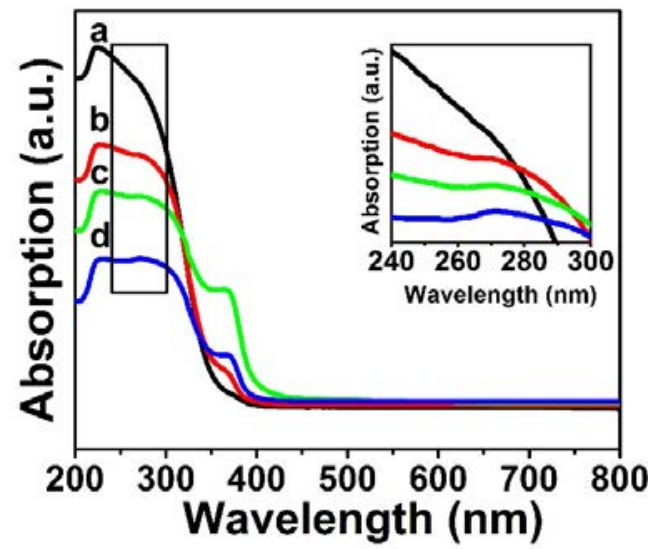

Fig. 2. Diffuse reflectance UV-vis spectra of ZnAl-MMO (a), $\mathrm{Zn}_{2} \mathrm{Zr}_{0.05} \mathrm{Al}-\mathrm{MMO}$ (b), $\mathrm{Zn}_{2} \mathrm{Zr}_{0.1} \mathrm{Al}-\mathrm{MMO}$ (c), and $\mathrm{Zn}_{2} \mathrm{Zr}_{0.2} \mathrm{Al}-\mathrm{MMO}$ (d) samples.

values of $12^{\circ}, 24^{\circ}, 34.9^{\circ}, 39^{\circ}, 61^{\circ}$, and $62^{\circ}$, which were indexed to the (003), (006), (009), (015), (110), and (113) reflection planes of an LDH phase. No other crystalline phase was detected, implying high purity of the LDH precursors. However, as the $\mathrm{Zr}$ content increased, the crystallinity of $\mathrm{Zn}_{2} \mathrm{Zr}_{x} \mathrm{Al}$-LDH decreased, indicated by weakened reflection intensity, which is due to the distortion of the LDH host caused by the introduction of the $\mathrm{Zr}^{4+}$ cation into the brucite-like layers. Fig. 1 (B) illustrates XRD patterns of the as-obtained $\mathrm{Zn}_{2} \mathrm{Zr}_{x} \mathrm{Al}-\mathrm{MMO}$ samples after calcination treatment of the LDH precursors at 500 ${ }^{\circ} \mathrm{C}$. In all cases, LDH samples undergo a structural topotactic transformation process, resulting in the disappearance of the characteristic reflections of the $\mathrm{LDH}$; while a series of reflections at $2 \theta$ values of $31.6^{\circ}, 34.2^{\circ}, 36^{\circ}, 47.3^{\circ}, 56.5^{\circ}, 62.6^{\circ}$, and $67.8^{\circ}$ are observed, corresponding to the $\mathrm{ZnO}$ phase (PDF\#36-1451). No zirconium oxide or alumina oxide phase was detected, suggesting an amorphous phase.

UV-vis diffuse reflectance spectroscopy (Fig. 2) was employed to study the structure of the $\mathrm{Zn}_{2} \mathrm{Zr}_{x} \mathrm{Al}$-MMO samples. All the samples showed an absorption peak at $375 \mathrm{~nm}$, which is
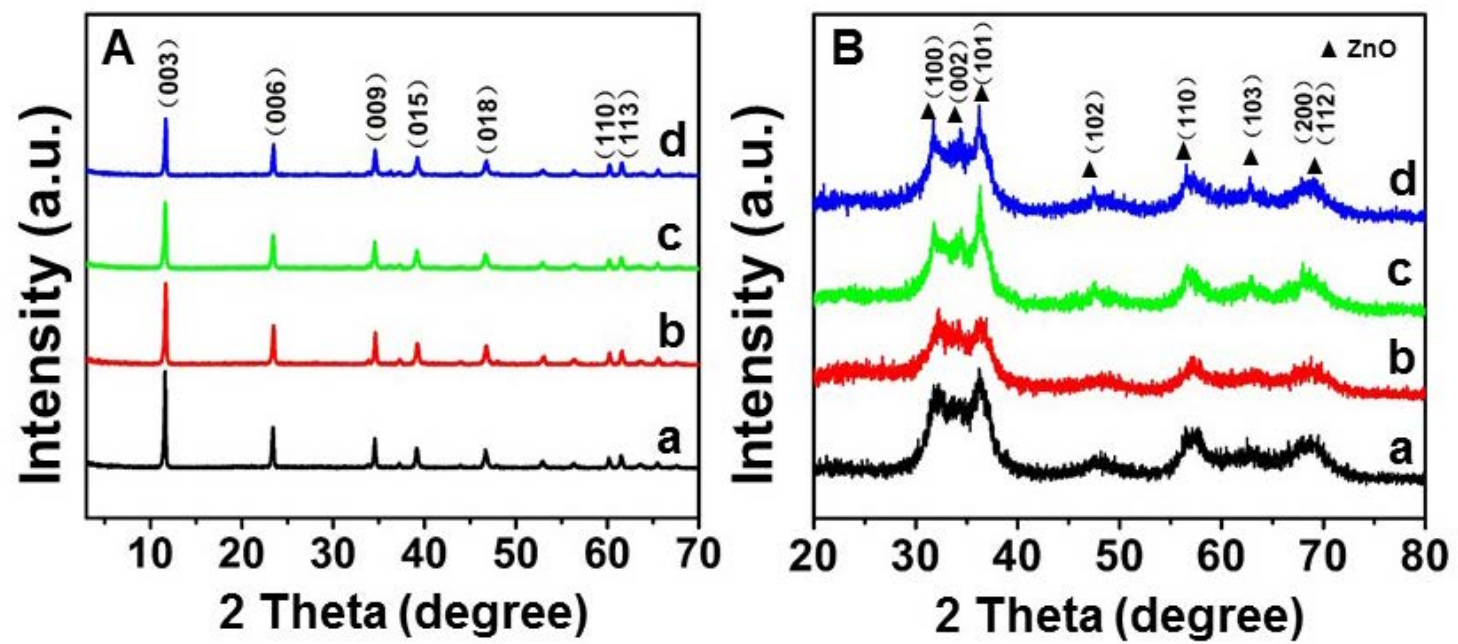

Fig. 1. (A) XRD patterns of $\mathrm{ZnAl-LDH} \mathrm{(a),} \mathrm{Zn}_{2} \mathrm{Zr}_{0.05} \mathrm{Al}-\mathrm{LDH}$ (b), $\mathrm{Zn}_{2} \mathrm{Zr}_{0.1} \mathrm{Al}-\mathrm{LDH}$ (c), and $\mathrm{Zn}_{2} \mathrm{Zr}_{0.2} \mathrm{Al}-\mathrm{LDH}$ (d); (B) XRD patterns of $\mathrm{ZnAl-MMO}$ (a), $\mathrm{Zn}_{2} \mathrm{Zr}_{0.05} \mathrm{Al}-\mathrm{MMO}$ (b), Zn2Zro.1Al-MMO (c), and Zn $\mathrm{Zr}_{0.2} \mathrm{Al}-\mathrm{MMO}$ (d). 


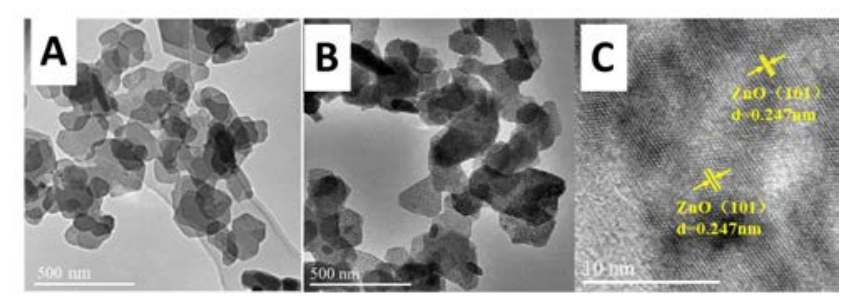

Fig. 3. TEM images of $\mathrm{Zn}_{2} \mathrm{Zr}_{0.1} \mathrm{Al}-\mathrm{LDH}(\mathrm{A})$ and $\mathrm{Zn}_{2} \mathrm{Zr}_{0.1} \mathrm{Al}-\mathrm{MMO}$ (B); (C) HRTEM image of $\mathrm{Zn}_{2} \mathrm{Zr}_{0.1} \mathrm{Al}-\mathrm{MMO}$ sample.

ascribed to the $\mathrm{ZnO}$ phase resulting from the transition of 0 $(2 p)-Z n(4 s-p)$ [29]. A weak band at $\sim 270 \mathrm{~nm}$ was observed in the three samples incorporating $\mathrm{Zr}$ and is attributed to $\mathrm{ZrO}_{2}$ nanoparticles [30]. It should be noted that with the increase in $\mathrm{Zr}$ content, the band intensity at $\sim 270 \mathrm{~nm}$ gradually increased, indicating the presence of $\mathrm{ZrO}_{2}$ in the $\mathrm{Zn}_{2} \mathrm{Zr}_{x} \mathrm{Al}-\mathrm{MMO}(x=0.05$, $0.1,0.2$ ) samples.

SEM images of the $\mathrm{Zn}_{2} \mathrm{Zr}_{x} \mathrm{Al}$-LDH precursors show a uniform nanoplate-like shape with a lateral diameter distribution of 180-200 nm; the $\mathrm{Zn}_{2} \mathrm{Zr}_{x} \mathrm{Al}-\mathrm{MMO}$ samples inherit the original plate-like morphology of LDHs without an obvious change in particle size (Fig. S1). As a typical example, TEM images of $\mathrm{Zn}_{2} \mathrm{Zr}_{0.1} \mathrm{Al}-\mathrm{LDH}$ and $\mathrm{Zn} 2 \mathrm{Zr}$.1Al-MMO display sheet-like shapes with particle sizes of 180-200 nm (Fig. 3 (A) and 3 (B)). A lattice fringe with a spacing of $0.247 \mathrm{~nm}$ was observed for the $\mathrm{Zn}_{2} \mathrm{Zr}$.1Al-MMO sample, which corresponds to the (101) reflection plane of the $\mathrm{ZnO}$ phase (Fig. $3(\mathrm{C})$ ). No $\mathrm{Al}_{2} \mathrm{O}_{3}$ reflections were observed, indicating an amorphous phase. Moreover, we did not observe the lattice fringe of $\mathrm{ZrO}_{2}$, possibly due to its low content and poor crystallinity. The nitrogen adsorption-desorption isotherms (Table 1) of the $\mathrm{Zn}_{2} \mathrm{Zr}_{x} \mathrm{Al}-\mathrm{MMO}$ samples indicated comparable specific surface areas, average pore sizes, and total pore volumes.

\subsection{Catalyst evaluation and structure-property correlation studies}

The conversion of ethanol with urea to produce DEC occurs in two consecutive steps: formation of the intermediate product EC, followed by reaction of EC with ethanol to produce DEC [31]. We studied the influence of the $\mathrm{Zn} / \mathrm{Al}$ ratio on catalytic
Table 1

Physicochemical parameters and catalytic performances of $\mathrm{Zn}_{2} \mathrm{Zr}_{x} \mathrm{Al}-\mathrm{MMO}$ samples toward DEC synthesis from ethanol.

\begin{tabular}{lccccc}
\hline Sample & $\begin{array}{c}S_{\mathrm{BET}^{\mathrm{a}}} \\
\left(\mathrm{m}^{2} \mathrm{~g}^{-1}\right)\end{array}$ & $\begin{array}{c}D_{\mathrm{BJH}}{ }^{\mathrm{b}} \\
(\mathrm{nm})\end{array}$ & \multicolumn{2}{c}{$V_{\mathrm{BJH}^{\mathrm{c}}}$} & \multicolumn{2}{l}{ Product yield (\%) } \\
\cline { 6 - 7 }$\left(\mathrm{cm}^{3} \mathrm{~g}^{-1}\right)$ & $\mathrm{EC}$ & $\mathrm{DEC}$ \\
\hline $\mathrm{Zn}$ 2Al-MMO & 88.27 & 4.67 & 0.1125 & 54.7 & 28.3 \\
$\mathrm{Zn}_{2} \mathrm{Zr}_{0.05} \mathrm{Al}-\mathrm{MMO}$ & 51.89 & 6.95 & 0.0972 & 47.6 & 36.6 \\
$\mathrm{Zn}_{2} \mathrm{Zr}_{0.1} \mathrm{Al}-\mathrm{MMO}$ & 48.99 & 7.27 & 0.0889 & 35.3 & 42.1 \\
$\mathrm{Zn}_{2} \mathrm{Zr}_{0.2} \mathrm{Al}-\mathrm{MMO}$ & 47.38 & 8.40 & 0.0825 & 33.0 & 38.1 \\
\hline
\end{tabular}

Reaction conditions: $200{ }^{\circ} \mathrm{C}$, ethanol/urea molar ratio of $15,10 \mathrm{wt} \%$ of urea, $5 \mathrm{~h}$. ${ }^{a}$ BET surface area. ${ }^{\mathrm{b}}$ Average pore diameter according to Barrett-Joyner-Halenda $(\mathrm{BJH})$ desorption. ${ }^{\mathrm{c}}$ Cumulative pore volume based on BJH desorption.

performance, and the results showed that the optimal catalytic behavior was obtained with $\mathrm{Zn} / \mathrm{Al}=2$. Catalytic evaluations of the $\mathrm{Zn}_{2} \mathrm{Zr}_{x} \mathrm{Al}$-MMO samples for ethanol conversion to DEC were performed (Fig. 4 (A), Tables 1 and S3). It was observed that the $\mathrm{Zn}_{2} \mathrm{Al}-\mathrm{MMO}$ catalyst showed the lowest yield of DEC (28.3\%) among the catalysts. As the $\mathrm{Zr}$ content increased, the DEC yield first increased and then declined, and the $\mathrm{Zn}_{2} \mathrm{Zr}_{0.1} \mathrm{Al}-\mathrm{MMO}$ catalyst exhibited the maximum yield of DEC (42.1\%). This is, to the best of our knowledge, the highest value reported for metal oxide catalysts (Table S1) [10,13,21,31,32]. Furthermore, the recyclability and stability of the $\mathrm{Zn}_{2} \mathrm{Zr}_{0.1} \mathrm{Al}-\mathrm{MMO}$ catalyst were also studied (Fig. 4 (B)). The DEC yield showed a slight decrease of $\sim 2 \%$ after five reaction cycles. In addition, the XRD pattern of the used catalyst (Fig. 4 (C)) displayed no significant variation from that of the fresh catalyst. Nitrogen adsorption-desorption isotherms (Table S2) indicate an $\sim 16 \%$ decrease in specific surface area after five reaction cycles, demonstrating satisfactory reusability.

It has been reported that the acid-base properties of the catalyst are crucial for alcohol conversion [34,36]. Herein, $\mathrm{CO}_{2}$-TPD and $\mathrm{NH}_{3}$-TPD measurements were performed (Fig. 5 and Table 2) in order to determine the concentration of the acidic and basic sites and the strength of the acid-base properties of the $\mathrm{Zn}_{2} \mathrm{Zr}_{x} \mathrm{Al}-\mathrm{MMO}$ catalysts. In the $\mathrm{CO}_{2}$-TPD curves, all four samples display a broad $\mathrm{CO}_{2}$ desorption peak between 100 and $400{ }^{\circ} \mathrm{C}$, which were deconvoluted into three contributions with maximum temperatures $\left(T_{\mathrm{M}}\right)$ in the ranges of $120-140{ }^{\circ} \mathrm{C}$ (weak base site), $180-200{ }^{\circ} \mathrm{C}$ (medium-strong base site) and 260-280 ${ }^{\circ} \mathrm{C}$ (strong base site) using a Gaussian peak fitting
(A)

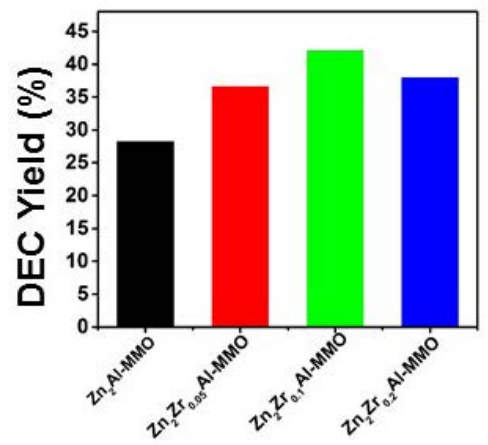

(B)

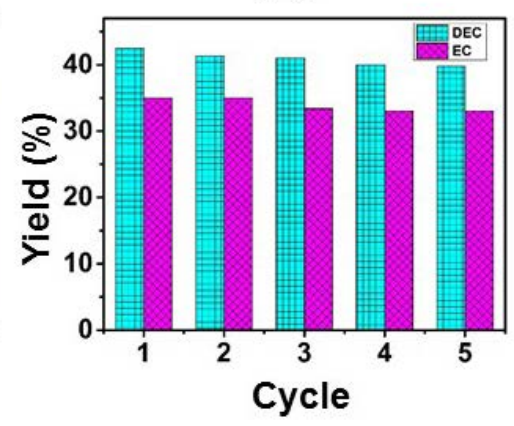

(C)

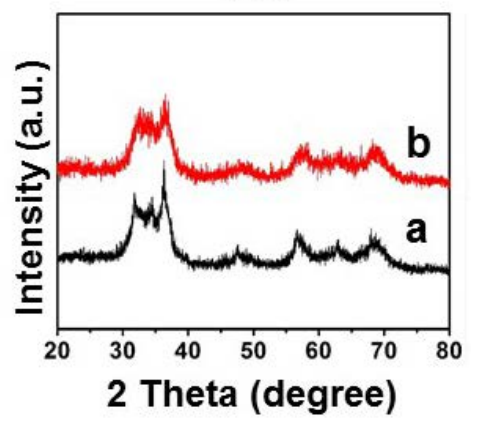

Fig. 4. (A) Catalytic performance of the catalysts; (B) Catalytic performance of $\mathrm{Zn}_{2} \mathrm{Zr}_{0.1} \mathrm{Al}$-MMO in five consecutive cycles; (C) XRD patterns of fresh (a) and used (b) $\mathrm{Zn}_{2} \mathrm{Zr}_{0.1} \mathrm{Al}-\mathrm{MMO}$ catalyst. 

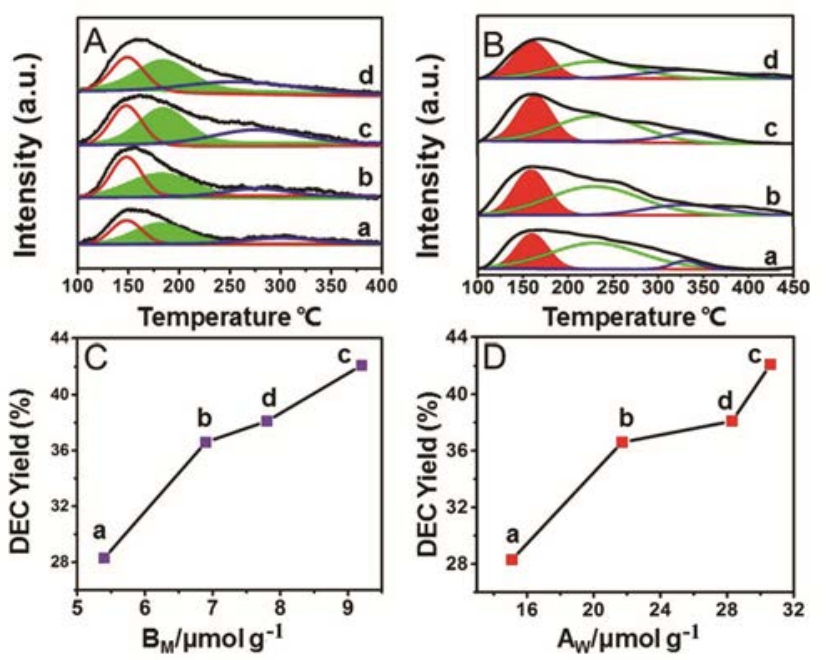

Fig. 5. $\mathrm{CO}_{2}$-TPD (A) and $\mathrm{NH}_{3}$-TPD (B) profiles of ZnAl-MMO (a),

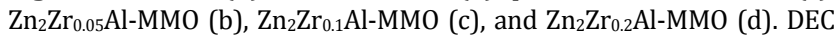
yield as a function of the concentration of medium-strong base sites (C) and weak acid sites (D) over ZnAl-MMO (a), $\mathrm{Zn}_{2} \mathrm{Zr}_{0.05} \mathrm{Al}$-MMO (b), $\mathrm{Zn}_{2} \mathrm{Zr}_{0.1} \mathrm{Al}-\mathrm{MMO}$ (c), and $\mathrm{Zn}_{2} \mathrm{Zr}_{0.2} \mathrm{Al}-\mathrm{MMO}$ (d).

method [35-37]. The basic sites originate from $\mathrm{OH}$ groups (weak), $\mathrm{M}^{+}-\mathrm{O}^{2-}$ pairs (medium), and isolated $\mathrm{O}^{2-}$ ions (strong), respectively. In the case of the $\mathrm{NH}_{3}$-TPD measurements, the $\mathrm{NH}_{3}$ desorption peak in the range of $100-450{ }^{\circ} \mathrm{C}$ was fitted to three peaks with $\mathrm{T}_{\mathrm{M}}$ in the region of $140-160{ }^{\circ} \mathrm{C}$ (weak acid site), $220-240{ }^{\circ} \mathrm{C}$ (medium-strong acid site), and $320-360{ }^{\circ} \mathrm{C}$ (strong acid site), respectively. The acid sites were derived from the contributions of a variety of metal oxides, such as $\mathrm{Al}_{2} \mathrm{O}_{3}$ and $\mathrm{ZnO}$. It should be noted that both the total basic site concentration (ВТотАL) and total acid site concentration (АтотАL) increased gradually from $\mathrm{Zn}_{2} \mathrm{Al}-\mathrm{MMO}$ to $\mathrm{Zn}_{2} \mathrm{Zr}_{0.1} \mathrm{Al}-\mathrm{MMO}$, and

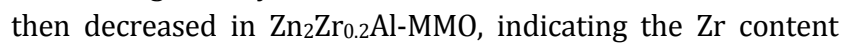
plays a key role in tuning the acid-base properties of the $\mathrm{Zn}_{2} \mathrm{Zr}_{x} \mathrm{Al}$-MMO catalysts. With an increase in $\mathrm{Zr}$ content, the concentration of the medium-strong base sites (BM) and the weak acid sites $\left(A_{w}\right)$ increased significantly and reached a maximum in the $\mathrm{Zn}_{2} \mathrm{Zr}_{0.1} \mathrm{Al}-\mathrm{MMO}$ catalyst. Moreover, we studied the DEC yield as a function of unique structure concentration, and the results showed a positive correlation between DEC yield and $\mathrm{B}_{\mathrm{M}}$ and $\mathrm{A}_{\mathrm{W}}$ (Fig. 5); however, this is not observed for other types of base or acid sites. These results imply that both medium-strong base and weak acid sites contribute to catalytic performance in the synthesis of DEC from ethanol and urea. The used $\mathrm{Zn}_{2} \mathrm{Zr}_{0.1} \mathrm{Al}-\mathrm{MMO}$ was characterized by $\mathrm{CO}_{2}$-TPD
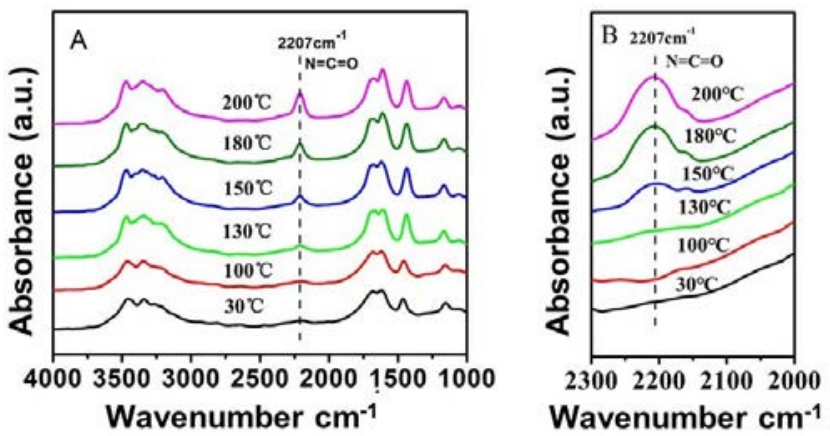

Fig. 6. In situ FTIR absorption spectra of urea (A) and EC (B) on the surface of the $\mathrm{Zn}_{2} \mathrm{Zr}_{0.1} \mathrm{Al}-\mathrm{MMO}$ catalyst in the temperature range of $30-200^{\circ} \mathrm{C}$

and $\mathrm{NH}_{3}$-TPD, and the ratio of desorption peaks did not show an obvious change (Fig. S2).

We prepared a control sample ( $\left.\mathrm{Zn}_{2} \mathrm{Al}-\mathrm{MMO}\right)$ for a comparison study. It was found that the $\mathrm{Zn} 2 \mathrm{Al}-\mathrm{MMO}$ sample produced the highest yield of EC (54.7\%) and the lowest yield of DEC (28.3\%) among all the catalysts (Table 1), indicating that the intermediate EC is not effectively activated and converted into DEC in the absence of $\mathrm{ZrO}_{2}$. Moreover, both $\mathrm{ZrO}_{2}$ and $\mathrm{Al}_{2} \mathrm{O}_{3}$ show high yields of EC (68.0\% and $81.2 \%)$ but low yields of DEC (8.7\% and 5.3\%), as shown in Table S1. This indicates that the ethanol molecule does not undergo effective activation so as to react with $\mathrm{EC}$ in the absence of $\mathrm{ZnO}$. We identified weak acid sites on the surface of $\mathrm{ZrO}_{2}$ and medium-strong basic sites on $\mathrm{ZnO}$ based on the structure-property correlations in this work, as well as in previous studies. Based on the in situ FTIR absorption spectra of control samples, it is proposed that urea and intermediate EC are activated by weak acid sites $\left(\mathrm{ZrO}_{2}\right)$; whereas ethanol is activated by medium-strong basic sites $\left(\mathrm{Zn}^{2^{+}-\mathrm{O}^{2-}}\right)$.

Furthermore, in situ FTIR absorption spectroscopy was employed to study the role of the acid sites of $\mathrm{Zn}_{2} \mathrm{Zr}_{0.1} \mathrm{Al}-\mathrm{MMO}$ (Fig. 6 (A)), in which urea and intermediate EC were used as basic species to probe the acid sites. For the adsorption of urea on the $\mathrm{Zn}_{2} \mathrm{Zr}_{0.1} \mathrm{Al}-\mathrm{MMO}$ sample, at room temperature, multiple bands were observed at 3456, 3355, 1683, and $1152 \mathrm{~cm}^{-1}$, which were attributed to $\mathrm{N}-\mathrm{H}, \mathrm{C}=\mathrm{O}$, and $\mathrm{C}-\mathrm{N}$ stretching vibrations, respectively [38,39]. As the temperature increased to 130 ${ }^{\circ} \mathrm{C}$, a new band appeared at $2207 \mathrm{~cm}^{-1}$, corresponding to $\mathrm{W}=\mathrm{C}=0$ bonding to the surface of the metal oxide $(\mathrm{O}=\mathrm{C}=\mathrm{N}-M, M$ stands for metal cation) [40], which originated from the activation of urea on the acid sites of the $\mathrm{Zn}_{2} \mathrm{Zr}_{0.1} \mathrm{Al}-\mathrm{MMO}$ catalyst at high temperature. Additionally, the intensity of the band at 2207

Table 2

Base and acid site concentrations for the $\mathrm{Zn}_{2} \mathrm{Zr}_{x} \mathrm{Al}-\mathrm{MMO}$ samples.

\begin{tabular}{|c|c|c|c|c|c|c|c|c|}
\hline \multirow{2}{*}{ Sample } & \multicolumn{4}{|c|}{ Base sites $\left(\mu \mathrm{mol} \mathrm{g}{ }^{-1}\right)$} & \multicolumn{4}{|c|}{ Acid sites $\left(\mu \mathrm{mol} \mathrm{g}{ }^{-1}\right)$} \\
\hline & BтотAL $^{\text {a }}$ & $\mathrm{Bw}^{\mathrm{b}}$ & $\mathrm{B}_{\mathrm{M}}^{\mathrm{b}}$ & $\mathrm{B}_{\mathrm{s}}^{\mathrm{b}}$ & Aтотац $^{\mathrm{c}}$ & $A w^{d}$ & $\mathrm{AM}_{\mathrm{M}}^{\mathrm{d}}$ & $A s^{d}$ \\
\hline $\mathrm{Zn}_{2} \mathrm{Al}-\mathrm{MMO}$ & 12.3 & 4.0 & 5.4 & 2.9 & 54.8 & 15.1 & 36.3 & 3.4 \\
\hline $\mathrm{Zn}_{2} \mathrm{Zr}_{0.05} \mathrm{Al}-\mathrm{MMO}$ & 16.6 & 6.6 & 6.9 & 3.1 & 70.1 & 21.7 & 36.8 & 11.6 \\
\hline $\mathrm{Zn}_{2} \mathrm{Zr}_{0.1} \mathrm{Al}-\mathrm{MMO}$ & 22.6 & 7.1 & 9.2 & 6.3 & 89.2 & 30.6 & 43.6 & 15.0 \\
\hline $\mathrm{Zn}_{2} \mathrm{Zr}_{0.2} \mathrm{Al}-\mathrm{MMO}$ & 18.8 & 6.5 & 7.8 & 4.5 & 74.5 & 28.3 & 29.8 & 16.4 \\
\hline
\end{tabular}

${ }^{\mathrm{a}} \mathrm{B}_{\text {Tотан }}$ represents the total quantity of base sites calculated from $\mathrm{CO}_{2}$-TPD. ${ }^{\mathrm{b}} \mathrm{B}_{\mathrm{W}}, \mathrm{B}_{\mathrm{M}}$, and $\mathrm{Bs}$ denote the concentrations of weak, medium-strong, and strong base sites. ${ }^{c} \mathrm{~A}_{\text {TотAL }}$ is the total quantity of acid sites calculated from $\mathrm{NH}_{3}$-TPD. ${ }^{\mathrm{d}} \mathrm{A}_{W}, \mathrm{~A}_{\mathrm{M}}$ and $\mathrm{A}_{\mathrm{S}}$ are assigned to the concentrations of weak, medium-strong, and strong acid sites. 
$\mathrm{cm}^{-1}$ increased significantly as the temperature increased from 130 to $200{ }^{\circ} \mathrm{C}$, demonstrating that a higher temperature is favorable for the activation adsorption of urea. In the in situ FTIR absorption of intermediate EC on the catalyst surface (Fig. 6 (B)), a similar phenomenon was observed; the band at 2207 $\mathrm{cm}^{-1}$, due to $\mathrm{O}=\mathrm{C}=\mathrm{N}-\mathrm{M}$, was detected at $130{ }^{\circ} \mathrm{C}$ and then increased gradually between 130 and $200{ }^{\circ} \mathrm{C}$, as a result of the adsorption of EC. The results confirm that both urea and EC undergo activation adsorption on the acid sites of the $\mathrm{Zn}_{2} \mathrm{Zr}_{0.1} \mathrm{Al}-\mathrm{MMO}$ catalyst.

In situ FTIR absorption spectra of ethanol on the surface of $\mathrm{Zn}_{2} \mathrm{Zr}_{0.1} \mathrm{Al}-\mathrm{MMO}$ were carried out (Fig. 7), in which ethanol was used as an acidic species to detect basic sites. In the temperature range of $100-200{ }^{\circ} \mathrm{C}$, five bands, attributed to ethoxide species, were observed at 2973, 2925, 2900, 1078, and 1052 $\mathrm{cm}^{-1}$, which are assigned as follows: $v_{\mathrm{as}}\left(\mathrm{CH}_{3}\right)$ stretching $(2973$ $\left.\mathrm{cm}^{-1}\right)$; $v_{\mathrm{as}}\left(\mathrm{CH}_{2}\right)$ stretching $\left(2925 \mathrm{~cm}^{-1}\right) ; v_{\mathrm{s}}\left(\mathrm{CH}_{3}\right)$ stretching $\left(2900 \mathrm{~cm}^{-1}\right)$; monodentate ethoxide stretching $v\left(\mathrm{CO}_{\mathrm{mono}}\right)$ (1078 $\left.\mathrm{cm}^{-1}\right)$, and bidentate ethoxide stretching $v\left(\mathrm{CO}_{\mathrm{bi}}\right)\left(1052 \mathrm{~cm}^{-1}\right)$ $[41,42]$. The ethoxide species originated from deprotonated ethanol (dissociation adsorption) on the basic sites of the $\mathrm{Zn}_{2} \mathrm{Zr}_{0.1} \mathrm{Al}-\mathrm{MMO}$ catalyst. Moreover, the band intensities of ethoxide species became stronger with an increase in temperature, suggesting an enhanced activation adsorption of the ethanol molecule on the catalyst surface.

\section{Conclusions}

In summary, ZnZrAl-MMO catalysts were synthesized by the structural topotactic transformation process of LDH precursors. The $\mathrm{Zn}_{2} \mathrm{Zr}_{0.1} \mathrm{Al}-\mathrm{MMO}$ catalyst exhibits the optimal catalytic performance (DEC yield 42.1\%) for ethanol conversion to synthesize DEC. The $\mathrm{CO}_{2}$-TPD and $\mathrm{NH}_{3}$-TPD studies indicate that weak acid and medium-strong base sites account for the enhancement of the DEC yield. According to in situ FTIR investigations, the acid sites of the $\mathrm{Zn}_{2} \mathrm{Zr}_{0.1} \mathrm{Al}-\mathrm{MMO}$ catalyst activate urea and the intermediate $\mathrm{EC}$ to produce $\mathrm{O}=\mathrm{C}=\mathrm{N}-\mathrm{M}$; while the base

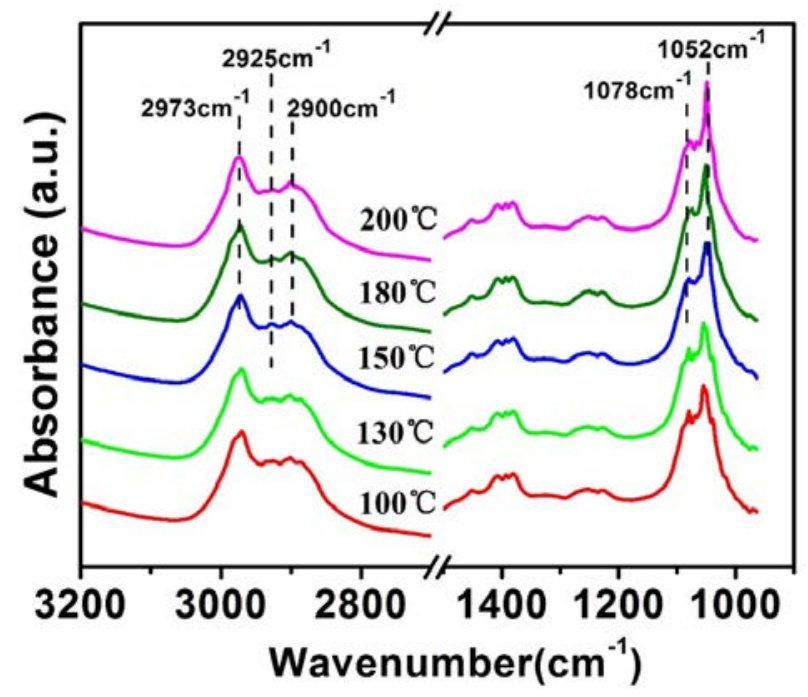

Fig. 7. In situ FTIR absorption spectra of ethanol over the $\mathrm{Zn}_{2} \mathrm{Zr}_{0.1} \mathrm{Al}-\mathrm{MMO}$ catalyst in the temperature range of $100-200{ }^{\circ} \mathrm{C}$. sites promote activation adsorption of ethanol, with the formation of ethoxide species. This study demonstrates a helpful paradigm for the control over acid-base bifunctional catalysts derived from LDH precursors, which will be of use in heterogeneous acid-base catalytic reactions.

\section{Acknowledgments}

This work was supported by the National Key R\&D Program (2017YFA0206804), the National Natural Science Foundation of China (21871021, 21521005), and the Fundamental Research Funds for the Central Universities (buctylkxj01, XK1802-6).

\section{References}

[1] T. L. Jordison, C. T. Lira, D. J. Miller, Ind. Eng. Chem. Res., 2015, 54, 10991-11000.

[2] K. Van der Borght, V. V. Galvita, G. B. Marin, Appl. Catal. A, 2015, 504, 621-630.

[3] J. Quesada, R. Arreola-Sánchez, L. Faba, E. Díaz, V. M. Rentería-Tapia, S. Ordóñez, Appl. Catal. A, 2018, 551, 23-33.

[4] H. Chen, Y. Dai, X. Jia, H. Yu, Y. Yang, Green Chem., 2016, 18, 3048-3056.

[5] J. Sun, Y. Wang, ACS Catal., 2014, 4, 1078-1090.

[6] J. Chen, J. Sun, Y. Wang, Ind. Eng. Chem. Res., 2017, 56, 4627-4637.

[7] B. Schäffner, F. Schäffner, S. P. Verevkin, A. Börner, Chem. Rev., 2010, 110, 4554-4581.

[8] L. Wang, H. Li, S. Xin, F. Li, Catal. Commun., 2014, 50, 49-53.

[9] E. Leino, P. Mäki-Arvela, V. Eta, D. Y. Murzin, T. Salmi, J. P. Mikkola, Appl. Catal. A, 2010, 383, 1-13.

[10] D. Wang, B. Yang, X. Zhai, L. Zhou, Fuel Process. Technol., 2007, 88, 807-812.

[11] P. Ball, H. Füllmann, W. Heitz, Angew. Chem. Int. Ed, 1980, 19, 718-720.

[12] K. Shukla, V. C. Srivastava, Catal. Rev., 2017, 59, 1-43.

[13] K. Shukla, V. C. Srivastava, Fuel Process. Technol., 2017, 161, 116-124.

[14] B. C. Dunn, C. Guenneau, S. A. Hilton, J. Pahnke, E. M. Eyring, J. Dworzanski, H. L. C. Meuzelaar, J. Z. Hu, M. S. Solum, R. J. Pugmire, Energy Fuels, 2002, 16, 177-181.

[15] S. Huang, P. Chen, B. Yan, S. Wang, Y. Shen, X. Ma, Ind. Eng. Chem. Res., 2013, 52, 6349-6356.

[16] S. J. Wang, S. H. Cheng, P. H. Chiu, K. Huang, Ind. Eng. Chem. Res., 2014, 53, 5982-5995.

[17] C. C. Hu, P. H. Chiu, S. J. Wang, S. H. Cheng, J. Chem. Eng. Data, 2015, 60, 1487-1494.

[18] H. Iida, R. Kawaguchi, K. Okumura, Catal. Commun., 2018, 108, $7-11$.

[19] K. Shukla, V. C. Srivastava, RSC Adv., 2016, 6, 32624-32645.

[20] S. Huang, B. Yan, S. Wang, X. Ma, Chem. Soc. Rev., 2015, 44, 3079-3116.

[21] W. Zhao, W. Peng, D. Wang, N. Zhao, J. Li, F. Xiao, W. Wei, Y. Sun, Catal. Commun., 2009, 10, 655-658.

[22] A. Dibenedetto, A. Angelini, S. Fasciano, I. Pàpai, D. Curulla-Ferré, M. Aresta, J. $\mathrm{CO}_{2}$ Util., 2014, 8, 27-33.

[23] A. Dibenedetto, A. Angelini, M. Aresta, S. Fasciano, M. E. Cucciolito, F. Ruffo, B. M. Aresta, D. Curulla-Ferré, E. De Giglio, Appl. Catal. A, 2015, 493, 1-7.

[24] W. Bing, L. Zheng, S. He, D. Rao, M. Xu, L. Zheng, B. Wang, Y. Wang, M. Wei, ACS Catal., 2018, 8, 656-664. 


\section{Graphical Abstract}

Chin. J. Catal., 2019, 40: 515-522 doi: S1872-2067(19)63318-8

Zn-Zr-Al oxides derived from hydrotalcite precursors for ethanol conversion to diethyl carbonate

Jian Zhang, Tingting Yan, Yusen Yang, Jialue Sun, Yanjun Lin *, Min Wei *

Beijing University of Chemical Technology

Zn-Zr-Al mixed metal oxide catalysts were prepared via structural transformation of hydrotalcite precursors, which exhibited satisfactory catalytic performance toward ethanol conversion to diethyl carbonate.

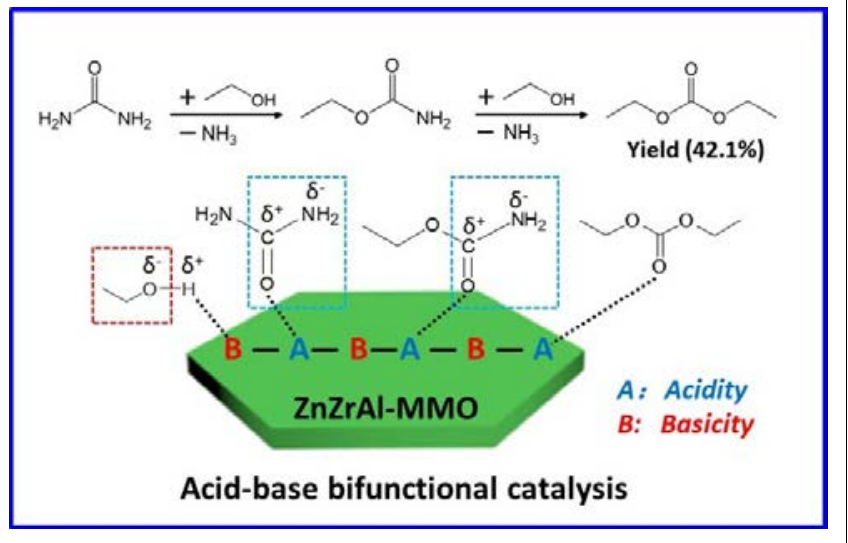

[25] G. Fan, F. Li, D.G. Evans, X. Duan, Chem. Soc. Rev., 2014, 43, 7040-7066.

[26] J. Pang, M. Zheng, L. He, L. Li, X. Pan, A. Wang, X. Wang, T. Zhang, J. Catal., 2016, 344, 184-193.

[27] Y. Chen, C. Li, J. Zhou, S. Zhang, D. Rao, S. He, M. Wei, D. G. Evans, X. Duan, ACS Catal., 2015, 5, 5756-5765.

[28] H. Chen, S. He, M. Xu, M. Wei, D. G. Evans, X. Duan, ACS Catal., 2017, 7, 2735-2743.

[29] R. Ullah, Z. Zhang, P. Bai, P. Wu, D. Han, U. J. Etim, Z. Yan, Ind. Eng. Chem. Res., 2016, 55, 3751-3758.

[30] Q. Pan, A. Ramanathan, W. K. Snavely, R. V. Chaudhari, B. Subramaniam, Ind. Eng. Chem. Res., 2013, 52, 15481-15487.

[31] S. Xin, L. Wang, H. Li, K. Huang, F. Li, Fuel Process. Technol., 2014, 126, 453-459.

[32] A. Angelini, A. Dibenedetto, D. Curullaferré, M. Aresta, RSC Adv., 2015, 5, 88401-88408.

[33] P. Gao, F. Li, H. Zhan, N. Zhao, F. Xiao, W. Wei, L. Zhong, H. Wang, Y. Sun, J. Catal., 2013, 298, 51-60.

[34] Z. Shi, S. Zhang, X. Xiao, D. Mao, G. Lu, Catal. Sci. Technol., 2016, 6, 3457-3467.

[35] X. Huang, C. Atay, T. I. Korányi, M. D. Boot, E. J. M. Hensen, ACS Catal., 2015, 5, 7359-7370.

[36] Q. Liu, B. Wang, C. Wang, Z. Tian, W. Qu, H. Ma, R. Xu, Green Chem., 2014, 16, 2604-2613.

[37] P. Liu, M. Derchi, E. J. M. Hensen, Appl. Catal. B, 2014, 144, $135-143$

[38] M. Aresta, A. Dibenedetto, F. Nocito, C. Ferragina, J. Catal., 2009, 268, 106-114.

[39] Y. Gao, W. Peng, N. Zhao, W. Wei, Y. Sun, J. Mol. Catal. A, 2011, 351, $29-40$.

[40] F. Li, H. Li, L. Wang, P. He, Y. Cao, Catal. Sci. Technol., 2015, 5, 1021-1034.

[41] C. P. Rodrigues, P. C. Zonetti, C. G. Silva, A. B. Gaspar, L. G. Appel, Appl. Catal. A, 2013, 458, 111-118.

[42] J. Llorca, N. Homs, P. R. D. L. Piscina, J. Catal., 2004, 227, 556-560.

\section{Zn-Zr-Al氧化物催化乙醇合成碳酸二乙酯}

张健, 阎婷婷, 杨宇森, 孙嘉略, 林彦军*, 卫 敏 ${ }^{*}$

北京化工大学, 化工资源有效利用国家重点实验室, 北京软物质科学与工程高精尖创新中心, 北京100029

摘要: 乙醇作为一种重要的可再生平台化学品, 其高值转化已引起研究者的广泛关注. 碳酸二乙酯(DEC)是乙醇转化的重 要衍生物, 作为合成中间体、绿色溶剂和燃油添加剂, 具有低毒、无污染的优点. 目前, 以乙醇为底物合成DEC主要有以下 方法: 光气法、氧化羰基化法、酯交换法和尿素醇解法. 其中, 尿素醇解法因成本低、操作简便、产物易分离等优点而备 受关注, 包括两个连续过程: 乙醇和尿素反应生成中间体氨基甲酸乙酯(EC), EC与乙醇进一步反应生成DEC. 本文采用水 滑石 $\left(\mathrm{Zn}_{2} \mathrm{Zr} \mathrm{r}_{x} \mathrm{Al}-\mathrm{LDH}\right)$ 为前体, 经结构拓扑转变制备了一系列酸碱双功能金属氧化物催化剂 $\left(\mathrm{Zn}_{2} \mathrm{Zr}_{x} \mathrm{Al}-\mathrm{MMO}\right)$, 用于催化乙醇 合成DEC. 通过改变LDHs前体元素比例调控氧化物的酸碱性质和催化性能, 最优催化剂 $\mathrm{Zn}_{2} \mathrm{Zr}_{0.1} \mathrm{Al}-\mathrm{MMO}$ 对产物DEC产率 达到 $42.1 \%$, 为目前报道的金属氧化物催化剂的最高产率.

$\mathrm{CO}_{2}-\mathrm{TPD}$ 和 $\mathrm{NH}_{3}-\mathrm{TPD}$ 结果表明, 随着 $\mathrm{Zr}$ 含量的增加, 催化剂的总碱性位点 $\left(\mathrm{B}_{\mathrm{TOTAL}}\right)$ 和总酸性位点 $\left(\mathrm{A}_{\mathrm{TOTAL}}\right)$ 浓度呈现先增 加后减少的趋势, 其中以 $\mathrm{Zn}_{2} \mathrm{Zr}_{0.1} \mathrm{Al}-\mathrm{MMO}$ 样品最大, 表明 $\mathrm{Zr}$ 对调节 $\mathrm{Zn}_{2} \mathrm{Zr}_{x} \mathrm{Al}-\mathrm{MMO}$ 催化剂酸碱性质起到了关键作用. 研究发 现, $\mathrm{Zn}_{2} \mathrm{Zr}_{0.1} \mathrm{Al}-\mathrm{MMO}$ 催化剂样品具有最大浓度的中强碱位点 $\left(\mathrm{B}_{\mathrm{M}}\right)$ 和弱酸位点 $\left(\mathrm{A}_{\mathrm{W}}\right)$. 为了揭示构效关系, 进一步研究了 DEC 产率与催化剂酸碱位点浓度的函数关系. 结果表明, DEC产率与中强碱位点(BM)或弱酸位点(AW)的浓度呈现正相关性; 而且中强碱位点和弱酸位点之间的协同作用对提升催化性能有重要贡献. 与目标催化剂相比, 对照样品 $\mathrm{Zn}_{2} \mathrm{Al}-\mathrm{MMO}$ 表现 
出较高的EC产率(54.7\%)和较低的DEC产率(28.3\%), 表明目标催化剂中的 $\mathrm{ZrO}_{2}$ 组分能够有效活化中间产物EC, 促使其进一 步转化为DEC. 此外, $\mathrm{ZrO}_{2}$ 和 $\mathrm{Al}_{2} \mathrm{O}_{3}$ 均显示出较高的EC产率(68.0\%和81.2\%), 但DEC产率(8.7\%和5.3\%)较低, 说明目标催化 剂中的 $\mathrm{ZnO}$ 组分能有效活化乙醇分子, 消耗生成的中间体EC. 原位红外结果证实, $\mathrm{ZrO}_{2}$ 提供的弱酸性位点促进了尿素和中 间产物 $\mathrm{E} C$ 的活化吸附, 在 $2207 \mathrm{~cm}^{-1}$ 处观察到 $v_{\mathrm{N}=\mathrm{C}=0}$ 特征吸附峰; 而乙醇在中强碱性位点 $\left(\mathrm{Zn}^{2+}-\mathrm{O}^{2-}\right)$ 活化, 在2973, 2925, 2900, 1078 和 $1052 \mathrm{~cm}^{-1}$ 处观察到乙醇的特征吸收峰. 此外, $\mathrm{Zn}_{2} \mathrm{Zr}_{0.1} \mathrm{Al}-\mathrm{MMO}$ 催化剂表现出良好的稳定性和可重复使用性, 循环使 用5次后, DEC产率损失低于 $5 \%$.

关键词: 水滑石; 金属氧化物; 酸碱催化反应; 乙醇转化

收稿日期: 2018-10-29. 接受日期: 2019-01-05. 出版日期: 2019-04-05.

*通讯联系人. 电话: (010)64412131; 传真: (010)64425385; 电子信箱: linyj@mail.buct.edu.cn

\#通讯联系人. 电话: (010)64412131; 传真: (010)64425385; 电子信箱: weimin@mail.buct.edu.cn

基金来源：国家重大研发计划(2017YFA0206804); 国家自然科学基金(21871021，21521005); 中央高校基础研究基金(buctylkxj01, XK1802-6).

本文的电子版全文由Elsevier出版社在ScienceDirect上出版(http://www.sciencedirect.com/science/journal/18722067). 